International Journal of English Language Studies (IJELS)

ISSN: 2707-7578

DOI: $10.32996 /$ ijels

Website: https://al-kindipublisher.com/index.php/ijels

\title{
English for IT purposes: Moroccan Ethical Hackers as a Case Study
}

Lamiae Benchekroune

Faculty of Letters and Human Sciences, ELT Department, Ibn Zohr University, Agadir City, Morocco

Corresponding Author: Lamiae Benchekroune, E-mail: lamiae.benchekroune@edu.uiz.ac.ma

ARTICLE INFORMATION

Received: November 12, 2020

Accepted: December 18, 2020

Volume: 2

Issue: 5

DOI: 10.32996/ijels.2020.2.5.5

\section{KEYWORDS}

English for IT purposes, English

for Ethical Hackers, Morocco

\section{ABSTRACT}

This paper seeks to discuss the theme of English for IT purposes. In particular, this research article aims to highlight the role that English language might play for the cybersecurity experts. Two research objectives were fixed. First, to explore Moroccan cybersecurity specialists' attitudes towards learning English; and second, to sift the learning strategies Moroccan ethical hackers use in order to learn English. In terms of the angle from which the topic was addressed, a mixed design approach was deployed. A questionnaire was designed and administered among 55 participants. The results of the study revealed that Moroccan ethical hackers reflected that they are alert towards the necessity of learning English via both their convictions as well as the learning strategies that they use. In light of the findings, some implications are given.

\section{Introduction}

\subsection{Background}

The link between English language learning and IT is, in fact, immanent in both branches of ESP: English for Academic Purposes (EAP) and English for Occupational Purposes (EOP). That being said, English language proficiency became pivotal to both IT students as well as IT professionals. Considering the impact Americanization exerted on different fields, computer science fields were also influenced. Accordingly, English became the primary koine in many branches of IT. Amidst these areas, inherent is cybersecurity. To elucidate, manifold certificates in ethical hacking are taken in English such as, Certificate of Ethical Hacking (CEH). Moreover, miscellaneous courses on ethical hacking are taught in English (i.e., as is the case in platforms of Udemy, Cybrary and Coursera). Furthermore, many tutorials on ethical hacking in YouTube are offered in English. Withal, if one is to deepen research on the cybersecurity sphere by enrolling in a PhD for instance, English language skills are surely going to be required. Indeed, a major proportion of academic research articles and books in this field were composed in English. Forbye, it should be noted that many ransomware notes are sent in English.

\subsection{Significance of the Paper}

To the best of the author's knowledge, this study is the first of its type to highlight the link between English language proficiency and cybersecurity in Morocco. Moreover, thus far, it should be noted that worldwide, only one paper got to cover the interconnection between language and cybersecurity (Klavans, 2015). Nonetheless, two issues occur to be found in relation to Klavan's paper "Cybersecurity-What's Language Got to Do with It?" Indeed, the paper is not a research article and it does not revolve around the English language solely. Therefore, the avail of this paper is inherent in being the first worldwide to include a research section on English for cybersecurity purposes.

\section{Literature review}

\subsection{Previous studies}

Former studies that were concerned with the area of teaching English for IT purposes go as follows.

K C AL-KINDI CENTER $\mathbf{R}$ D FOR RESEARCH Your gatewoy to world-clas research
Published by Al-KindiCenter for Research and Development. Copyright (c) the author(s). This is an open access article under CC BY license (https://creativecommons.org/licenses/by/4.0/) 


\section{Studies in the MENAP region}

Studies in Morocco

In Morocco, Mahraj (2019) did a paper which he denominated "ESP Needs Analysis in Moroccan Higher Education: The Case of Computer Engineering Students". The research took place in the National School of Applied Sciences of Berrechid City in which 32 undergraduate Computer Engineering students partook in the answering of the survey. The outcomes showed that the students are facing difficulties in the three skills of listening, speaking and writing; yet, students' slants towards the necessity to learn English proved highly favorable. Further, findings revealed that a transformation needs to occur in the pedagogies employed; in particular, a learner-centered approach altogether with a task-based approach were highly recommended. In another context in the National School of Applied Sciences of Al-Hoceima City, Dahbi (2015) investigated two main objectives. First, to scrutinize the level to which the taught ESP course helps computer science graduates in the procedure of job integration. Second, to identify the ESP needs of computer science students. In another study, Jamiai (2018) wrote a research article entitled "ESP Course Design for Computer Science Students in Morocco: Perceptions and Satisfaction from a Project-Based Learning Perspective". As far as Jamiai's paper is concerned, interrogation occurred in the "Higher Institute of Technology' of Meknes City 'ESTM' where both students and the teacher got involved. It should be noted that utilizing Project-Based Learning (PBL) and Needs Analysis (NA) eventuated a satisfaction from sides of both the instructor and the learners.

\section{Studies in other countries of the MENAP region}

In Algeria, Dakhmouche (2008) carried out a study on the teaching of EFL for Computer Science students of the Mentouri University of Constantine (Mahmood, 2017 as cited in Nisar, 2016. Methodologically speaking, both teachers and students got involved with the research instrument being the questionnaire. Findings revealed the immanence of many problems. From the teachers' side for example, crowdedness of the classrooms was cited. As to the students, a discontentment with the nature of the ESP course was expressed: To them, the ESP course does not cater for the 'speaking-based activities' that they need (as cited in (Mahmood, 2017)). Besides Dakhmouche (2008), Mehdi (2012) conducted a study in Algeria as well. Alongside the questionnaire, another research tool that was deployed by Mehdi (2012) was observation. Apropos of the results, Computer Science students had a positive attitude towards the idea of having an ESP course amidst the curricula (Mahmood, 2017). Further identical studies which were conducted in Algeria do include "Implementing an ESP course to Computer Sciences Students: Case Study of Master's Students at the University of Mustapha Stambouli Mascara" by Benchennane (2018), and "English for Computer Science Students: Needs to Enhance Technical Writing at Tlemcen University" by Kourichi and Benyelles (2019). Besides, in Iran, Karimi and Mokhtarnia (2004) evinced the immanence of a relationship between English skills and IT skills (as cited in Rahimi \& Yadollahi, 2011). Moreover, in Saudi Arabia, in particular at the Faculty of Computing and IT which is affiliated to King Abdulaziz University, Fadel and Rajab (2017) analyzed the ESP needs of the female students.

\section{Studies in the West}

In People's Republic of China, Ho (2015) administered a study in which Computer Science students of the City University of Hong Kong participated. In this study, the role of the ESP course was examined especially in terms of the extent to which it prepares IT students to a better integration in the workplace (as cited in Mahmood, 2017). Likewise, in Thailand, Pholsward (1993) inquired into the most used writing tasks IT professionals do employ in work (as cited in Ho, 2015). Along the same line as well, in Japan, Kaneko et al. investigated the English language needs of Japanese IT specialists in the workplace (Ho, 2015). Besides, in Malaysia, notably at Putra University, Rahman (2012) explored the complications computer science students face while reading English texts for IT purposes (as cited in Fadel \& Rajab, 2017). Also, in Indonesia, Septiana, Petrus and Inderawati (2020) wrote a paper titled "Needs Analysis-Based English Syllabus for Computer Science Students of Bina Darma University".

\subsection{Intersections between English and IT}

Reporting Conti-Ramsden, Durkin and Walker's citation, it was stated that "students that have language problems and low English proficiency may be particularly vulnerable to experiencing anxiety in computer use" (Rahimi \& Yadollahi, 2010, p.176). There is, hence, a relation between lack in language proficiency and computer anxiety. Moreover, English is crucial for programming. Most commands of programming languages are, in fact, written in English. Actually, many programs were created in the US. Further, English is deemed to be the primary IT language. Indeed, a large amount of content existing in the Internet was written in English. In addition, in this era, the universe is globalized more than ever; accordingly, the workplace was internationalized (Vladislav, 1995). Considering English as a lingua franca, its mastery therefore is deemed a pre-requisite to the professional success of both the individual as well as the multinational companies MNCs (Vladislav, 1995), (Rajprasit \& 
Hemchua, 2015). Also, if one is to stay informed about the latest updates in software engineering, English is going to be extremely crucial (Todd, 2020). Finally, a direct link is inherent in computational linguistics.

\section{Methodology}

This study is to be categorized as a survey research. As for the data collection instrument, a questionnaire was created. The questionnaire was designed to include 9 questions distributed as follows: 7 questions for section $n^{\circ} 1$ and 2 questions for section $n^{\circ} 2$. Section 1 was devised in order to help answer the research objective $n^{\circ} 1$. In like manner, section $n^{\circ} 2$ was developed to meet the requirements for research objective $n^{\circ} 2$. As to the procedure, the questionnaire was posited in Google Forms; afterwards, a link was sent to the participants. That being said, the process was carried out online. Concerning the number of respondents, it was 55. While some of cybersecurity experts are affiliated to ' 1337 of Benguerir City', others do belong to '1337 of Khouribga city', 'YouCode of Safi City', 'YouCode of Youssoufia City', and 'ISGA of Tangiers City' with all the aforementioned schools being classified as Moroccan private institutes of IT.

\section{Results and Discussion}

\subsection{Results}

With regards to the first section, cybersecurity specialists' attitudes towards the necessity of learning English were investigated. The majority of participants asserted the significance of English mastery to the cybersecurity experts $(85.45 \%)$. To detail its importance, answerers believed in the worth of speaking $(81.81 \%)$, writing $(72.72 \%)$, listening $(70.9 \%)$ and reading (63.63\%). Furthermore, a great proportion of answers stressed the behoof of being in possession of an IT terminology in English (83.63\%). Additionally, (54.54\%) declared that they invest in English language learning.

As for the second section, results report on the strategies that Moroccan cybersecurity specialists deploy so as to learn English. The results revealed that whilst few are enrolled in language centers (9.09\%), numerous individuals do depend on autonomous learning (45.45\%). Concerning the independent learners' category, techniques cited by responders comprised: viewing films in English that are germane to the subject of ethical hacking (e.g. Mr. Robot, the Matrix, Tron, the Fifth Estate, Takedown, Who Am I), watching hacking tutorials on YouTube in English, buying textbooks on English for IT, and mastering general English beforehand.

\subsection{Discussion}

Regarding section 1, the results are in line with the literature. Antecedent studies on English for IT purposes equally accented the gain of mastering the four language skills of listening, speaking, reading and writing (Septiana et al., 2020), (Kourichi \& Benyelles, 2019), (Irshad \& Anwar, 2018), (Mahmood, 2017), (Nisar, 2016), (Ho, 2015). Prevenient papers on English for computer sciences also highlighted the merits of proficiency in the core language element of vocabulary (Septiana et al., 2020), (Kourichi \& Benyelles, 2019), (Fadel \& Rajab, 2017).

As to section 2, outcomes are also in congruence with the available body of literature. Pursuant to Nisar (2016), few were the computer science students who sought to learn English from sources beyond the classroom (i.e., extra hours). In addition, tactics cited by respondents are literally practical. Albeit not mentioned in literature that is directly related to English for IT, the use of media (e.g. films, YouTube, books) is acknowledged to be efficacious.

\section{Conclusion}

\subsection{Summary}

In sum, this paper addressed the topic of English mastery for cybersecurity specialists. Also, to recapitulate, two main research objectives were put forward. First, investigate the attitudes of Moroccan cybersecurity specialists towards the necessity of English language learning. Second, to probe the strategies Moroccan cybersecurity experts use in order to learn English. Findings for both questions reflected an ever-increasing awareness Moroccan ethical hacker do hold regarding the importance of learning English. Aforesaid consciousness was shown in both their positive attitudes altogether with the learning strategies they use.

\subsection{Significance \\ Practical applications}

Thus far, in Morocco, BKHS center of Casablanca City appears to be the sole private school to offer a certificate on English for IT purposes. Therefore, other private institutes need to be inaugurated all across Morocco. Also, the American Language Centers (ALCS) together with the British Councils of Morocco are highly recommended to create a course for IT professionals. Said establishment is also expected to train teachers of English for IT. Indeed, in Morocco, instructors of ESP were rather 
trained to teach English for General Purposes (EGP). Last but not least, opening courses on English for IT is expected to advance the quality of the ESP sector in Morocco.

\section{Research implications}

It is highly recommended that writers produce other research articles on this topic. Methodologically speaking, further ways may be implemented. Experimental designs, observations, journal diaries, interviews are exempli gratia to be cited. Additionally, theses at the level of the BA, MA and PhD need to be engendered on this subject area. Further, in terms of research, the topic which was tackled is not yet exhausted.

\section{Relevance}

In fine, this paper appears to be appurtenant. Indeed, considering the aims and the scope of the journal, ESP is amongst the journal's fields of interest. Along the same line, English for IT purposes is categorized under ESP.

Funding: This research received no external funding.

Conflict of interest: The author declares no conflict of interest.

\section{References}

[1] Benchennane, D. (2018). Implementing an ESP course to computer sciences students: Case study of master's students at the University of Mustapha Stambouli Mascara [Doctoral dissertation, Abou Bekr Belkaid University-Tlemcen]. dspace.univtlemcen. http://dspace.univ-tlemcen.dz/handle/112/12891

[2] Dahbi, M. (2015). Reassessing the English course offered to computer engineering students at the National School of Applied Sciences of Al-Hoceima in Morocco: An action research project. Africa Education Review, 12(3), 508-524.

https://www.researchgate.net/publication/291018517_Reassessing_the_English_Course_Offered_to_Computer_Engineering_Student s_at_the_National_School_of_Applied_Sciences_of_Al-Hoceima_in_Morocco_an_Action_Research_Project

[3] Fadel, S. \& Rajab, H. (2017). Investigating the English language needs of the female students at the Faculty of Computing and Information Technology at King Abdulaziz University in Saudi Arabia. English Language Teaching, 10(6), 69-82.

https://www.researchgate.net/publication/317203112_Investigating_the_English_Language_Needs_of_the_Female_Students_at_the _Faculty_of_Computing_and_Information_Technology_at_King_Abdulaziz_University_in_Saudi_Arabia

[4] Ho, B. (2015). English communication needs of computer science internship and workplace. International Journal of Language and Linguistics, 2(2), 9-20. http://ijllnet.com/journals/Vol_2_No_2_June_2015/2.pdf

[5] Irshad, I. \& Anwar, B. (2018). Designing English for specific purposes course for computer science students. Journal of Education and Educational Development, 5(1), 156-171. https://files.eric.ed.gov/fulltext/EJ1180630.pdf

[6] Jamiai, A. (2018). ESP course design for computer science students in Morocco: Perceptions and satisfaction from a project-based learning perspective. International Journal of Science and Research, 8(2), 1945-1956. https://pdfs.semanticscholar.org/1325/c583d2fbc6c1e975e58b1e87a3247f4628ff.pdf

[7] Klavans, J. L. (2015). Cybersecurity - What's language got to do with it? Retrieved from: https://drum.lib.umd.edu/bitstream/handle/1903/17165/LAMP-TR 158.pdf?sequence=1\&isAllowed=y

[8] Kourichi, M. \& Benyelles, R. (2019). English for computer science: Students' needs to enhance technical writing at Tlemcen University. Aleph, 12, 113-130. https://aleph-alger2.edinum.org/1825

[9] Mahmood, R. A. (2017). Needs analysis in ESP for computer science students at the University of Human Development [Master's thesis, Eastern Mediterranean University]. EMU repository. http://irep.emu.edu.tr:8080/xmlui/bitstream/handle/11129/4426/mahmoodrabar.pdf?sequence=1

[10] Mahraj, M. (2019). ESP needs analysis in Moroccan higher education. The case of computer engineering students. International Arab Journal of English for Specific Purposes, 2(1), 30-44. https://revues.imist.ma/index.php/IAJESP/article/view/18857/10242

[11] Nisar, S. (2016). The present English language needs of computer science undergraduates: A case study in International Islamic University, Islamabad (female campus), Academia. https://www.academia.edu/27298363/Present_English_Learning_Needs_of_Computer_Science_Students_IIUI_female_campus

[12] Rahimi. M \& Yadollahi, S. (2010). Success in learning English as a foreign language as a predictor of computer anxiety. Procedia Computer Science, 3, 175-182. https://core.ac.uk/download/pdf/82621444.pdf

[13] Rajprasit, K. \& Hemchua, S. (2015). The English language \& communication in the international workplace: An examination of Thai computer engineering professionals. The Southeast Asian Journal of English Language Studies, 21(3), $109-124$.

https://www.researchgate.net/publication/306030524_The_English_language_communication_in_the_international_workplace_An_ examination_of_Thai_computer_engineering_professionals

[14] Septiana, I., Petrus, I. \& Inderawati, R. (2020). Needs analysis-based English syllabus for computer science students of Bina Darma University. English Review: Journal of English Education, 8(2), 299-310. https://journal.uniku.ac.id/index.php/ERJEE/article/view/3027/1989

[15] Todd, A. (2020, August 28). The importance of English in technology careers. Voxy. https://voxy.com/blog/2020/08/the-importanceof-english-in-technology-careers/ 
[16] Vladislav, H. (1995). Role of the English language in Information Technology: Importance of learning and practical use of language skills. file:///C:/Users/Benchekroun/Downloads/1995-7068-1-PB\%20(2).pdf

\section{Appendix}

\section{Questionnaire}

\section{Section 1:}

- Being proficient in English is important for cybersecurity specialists in Morocco $\square$ Yes $\square$ No

- Being in hold of a good listening comprehension in English is important for the Moroccan cybersecurity specialists $\square$ Yes $\square$ No

- Being in possession of English speaking skills is important for Moroccan cybersecurity specialists $\square$ Yes $\square$ No

- Possessing good English writing skills is important for the Moroccan cybersecurity specialists $\square$ Yes $\square$ No

- Knowledge of how to read in English is important for the Moroccan cybersecurity specialists $\square$ Yes $\square$ No

- Mastery of IT terminology in English is important for Moroccan cybersecurity specialists $\square$ Yes $\square$ No

- As a cybersecurity specialist, do you invest in English language learning? $\square$ Yes $\square$ No

\section{Section 2:}

- If you invest on English language learning, is it by going to a language center or by learning independently?

- If you learn English independently, which strategy do you employ? 